University of Nebraska - Lincoln

DigitalCommons@University of Nebraska - Lincoln

Agronomy \& Horticulture -- Faculty Publications

Agronomy and Horticulture Department

1998

Growth Traits Among Sorghum Genotypes in Response to Aluminum

\author{
J. H. Bernal \\ University of Nebraska-Lincoln \\ R. B. Clark \\ Appalachian Soil \& Water Conservation Research Lab, USDA-ARS
}

Follow this and additional works at: https://digitalcommons.unl.edu/agronomyfacpub

Part of the Agricultural Science Commons, Agriculture Commons, Agronomy and Crop Sciences Commons, Botany Commons, Horticulture Commons, Other Plant Sciences Commons, and the Plant Biology Commons

Bernal, J. H. and Clark, R. B., "Growth Traits Among Sorghum Genotypes in Response to Aluminum" (1998). Agronomy \& Horticulture -- Faculty Publications. 822.

https://digitalcommons.unl.edu/agronomyfacpub/822

This Article is brought to you for free and open access by the Agronomy and Horticulture Department at DigitalCommons@University of Nebraska - Lincoln. It has been accepted for inclusion in Agronomy \& Horticulture -Faculty Publications by an authorized administrator of DigitalCommons@University of Nebraska - Lincoln. 
JOURNAL OF PLANT NUTRITION, 21(2), 297-305 (1998)

\title{
Growth Traits Among Sorghum Genotypes in Response to Aluminum
}

\author{
J. H. Bernala, ${ }^{a, 1}$ and R. B. Clark $^{b}$ \\ ${ }^{2}$ Department of Agronomy and USDA-ARS, University of Nebraska, Lincoln, \\ NE 68583

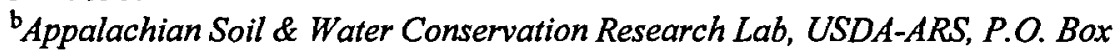 \\ 400, Beaver, WV 25813-0400
}

\begin{abstract}
Aluminum (Al) has many detrimental effects on plant growth, and shoots and roots are normally affected differently. A study was conducted to determine differences among sorghum [Sorghum bicolor (L.) Moench] genotypes with broad genetic backgrounds for growth traits of plants grown at $0,200,400,600$, and $800 \mu \mathrm{M} \mathrm{Al}$ in nutrient solutions (pH 4.0). Genotypes were categorized into "Al-sensitive", "intermediate Al-tolerant", "Al-tolerant", and SC 283 (an Al-tolerant standard). As Al increased, shoot and root dry matter (DM), net main axis root length (NMARL), and total root length (TRL) became lower than controls $(0 \mathrm{Al})$. Aluminum toxicity and/or nutrient deficiency symptoms become more severe, and shoot to root DM ratios and specific RL (TRL/root DM) values also changed as $\mathrm{Al}$ in solution increased. Root DM had greater changes among genotypes than shoot DM, and NMARL at $400 \mu \mathrm{M} \mathrm{Al}$, and TRL at $200 \mu \mathrm{M} \mathrm{Al} \mathrm{had} \mathrm{greater} \mathrm{differences} \mathrm{among} \mathrm{genotypes}$
\end{abstract}

'Present address: CORPICA-La Libertad, A.A. 2011, Villavicencio-Meta, Colombia, South America.

Copyright (C 1998 by Marcel Dekker, Inc. 
than root DM, ratings for toxicity and/or deficiency symptoms, and other DM and RL traits. The wide differences among genotypes for NMARL and TRL could be used more effectively to evaluate sorghum genotypes for tolerance to Al toxicity than the other growth traits.

\section{INTRODUCTION}

Aluminum toxicity is a major problem for plants grown on acidic soils, and has many detrimental effects on plant growth (Foy, 1992). Plants grown in media with Al normally exhibit Al toxicity and/or mineral deficiency symptoms, which often vary with plant genotype (Grundon et al., 1987). The short and stubby roots of $\mathrm{Al}$ affected plants usually have inhibited uptake of water and nutrients and cannot contact sufficient media to obtain needed nutrients, especially for soilgown plants, to maintain optimum growth. As such, Al affected plants do not normally grow well.

Liming has been the main management practice to correct soil acidity (Al toxicity) problems (Foy, 1984). Even though liming is relatively effective for alleviating soil acidity, this practice requires extensive monetary input and may not be practical in many plant production systems. An alternative solution for using extensive inputs for overcoming soil acidity has been to grow plants tolerant to the existing conditions (Foy, 1993). Many plant species and cultivars within species are known to tolerate soil acidity conditions, and have been used successfully in many plant production systems (Maranville et al., 1993).

Many traits have been used to select, identify, and evaluate plants for tolerance to Al toxicity in greenhouse/growth chamber studies, and many of these results have been verified in field studies (Flores et al., 1988; Foy, 1984; Howeler and Cadavid, 1976; Urrea-Gómez et al., 1996; L.M. Gourley, Mississippi State University, personal communication). Studies to evaluate germplasm for and understand $\mathrm{Al}$ toxicity tolerance problems as well as appropriate technologies to manage acid soil problems have been discussed and featured in various symposia in recent years (Barrow, 1993; Date et al., 1995; Maranville et al., 1993; Wright et al., 1991). Traits to distinguish Al-tolerant and Al-sensitive germplasm are important for screening and identifying plant tolerance to Al toxicity.

This study was conducted to determine differences among sorghum genotypes with broad genetic background for growth traits when grown at varied levels of Al.

\section{MATERIALS AND METHODS}

Sorghum seeds treated with captan [N-(trichloromethylthio)-4 cyclohexene1,2 dicarboximide] were germinated in rolled paper towels (Clark, 1982), and 4day-old seedlings were transferred to $6-\mathrm{L}$ of aerated 0.5 -strength nutrient solution and grown for five days. Uniform-sized 9-day-old seedlings of each genotype 
were transferred to 1.9-L containers (four plants container-1) containing fullstrength nutrient solution with treatments. The composition of full-strength nutrient solution was 19.88 (6:1 nitrate:ammonium) nitrogen $(\mathrm{N}), 7.54$ calcium $(\mathrm{Ca}), 7.24$ potassium $(\mathrm{K}), 1.94$ chlorine $(\mathrm{Cl}), 1.82 \mathrm{~S}, 1.55$ magnesium $(\mathrm{Mg})$, and 0.20 sodium $(\mathrm{Na})$ in $\mathrm{mM}$; and $65 \mathrm{P}, 50 \mathrm{~B}, 49$ iron (Fe) [as FeHEDTA (ferric hydroxyethylethylene diaminetriacetate)], 18 manganese $(\mathrm{Mn}), 4.6$ zinc $(\mathrm{Zn}), 1.6$ molybdenum (Mo), and 1.2 copper ( $\mathrm{Cu}$ ) in $\mu \mathrm{M}$ (Clark, 1982). Treatments consisted of $\mathrm{Al}$ at 0 , $200,400,600$, and $800 \mu \mathrm{M}$ as $\mathrm{KAl}\left(\mathrm{SO}_{4}\right)_{2}$ at $\mathrm{pH} 4.0 \pm 0.1$ which was monitored every other day and adjusted as needed during plant growth.

Plants were grown in growth chambers with light/dark conditions of $16 / 8 \mathrm{~h}$, $28 / 23 \pm 1^{\circ} \mathrm{C}$, and $50 / 60 \pm 5 \%$ relative humidity. Light was $300 \mu \mathrm{mol} \mathrm{m}^{-2} \mathrm{~s}^{-1}$ photon flux density at plant height and was provided by low pressure sodium and metal halide lamps. Because of the number of genotypes tested and space limitations, four similar experiments were conducted over time. Genotypes included in each experiment were selected at random with a standard sorghum genotype (SC 283) included in each. The experimental design was completely randomized with factorial arrangements for $\mathrm{Al}$ level and genotypes with four replications.

The length of the longest main axis root (MARL) was recorded when plants were put into treatment solutions (initial), and a series of plants were harvested at this time to provide initial DM. Plants were grown in treatments for 15 days after which experiments were terminated. At the conclusion of each experiment, severity of visual Al toxicity and/or mineral deficiency symptoms on each genotype was rated ( $1=$ no symptoms to $5=$ =severe symptoms). Shoots were severed from roots, and shoots were dried at $70^{\circ} \mathrm{C}$ and weighed. Roots were thoroughly rinsed with distilled water, final MARL measurements recorded, and fresh weights determined. Roots were cut into $1-2 \mathrm{~cm}$ segments, thoroughly mixed, and subsamples $(\sim 10 \mathrm{~g}$ fresh weight) were taken for TRL measurements using a gridline intersect method (Newman, 1966; Tennant, 1975). The remainder of the roots were dried and weighed as were root samples taken for TRL. The DM was final DM minus initial DM and NMARL was final MARL minus initial MARL.

The 25 genotypes tested (Table 1) were categorized into four groups according to NMARL readings. Genotypes with NMARL at $400 \mu \mathrm{M} \mathrm{Al}$ of $>70 \%$ those of SC 283 (standard Al-tolerant genotype) were categorized as "Al-tolerant" (B 68181 , BTX 623 , IS 7180 , and IS 7440); genotypes with NMARL of $<20 \%$ those of SC 283 were categorized as "Al-sensitive" (RTX 430, BTX 2783, BTX 3042, IS 9187 , IS 9919, and B Wheatland); genotypes with NMARL between 20 and $70 \%$ those of SC283 were categorized as "Intermediate Al-tolerance" (14 other genotypes listed in Table 1 not listed as Al-tolerant or Al-sensitive); and SC 283 was categorized as its own group.

Data were statistically analyzed using analyses of variance procedures in a General Linear Model of SAS (SAS, 1985) and converted to percent of controls $(0 \mathrm{Al})$. The $L S D$ values at $P=0.05$ were used to make relative comparisons among each genotypic group using the mean value of the genotypes making up that specific group. 
TABLE 1. Names, origin, and classification of sorghum germplasm grown with varied levels of $\mathrm{Al}$.

\begin{tabular}{|c|c|c|c|}
\hline Genotype & Origin & Classification & Other information \\
\hline SC 283 & Tanzania & Conspicuum & IS $7173 \mathrm{~B}$ line \\
\hline ICA-Nataima & Colombia & & \\
\hline BTX 631 & USA-Texas & & $\mathrm{B}$ line \\
\hline В 68181 & USA-Georgia & & B line \\
\hline BOK 11 & USA-Oklahoma & & B line \\
\hline BTX 3042 & USA-Texas & Redlan selection & $\mathrm{B}$ line \\
\hline BTX 623 & USA-Texas & & B line \\
\hline B Redlan & USA-Texas & & TX 378 B line \\
\hline BTX 2783 & USA-Texas & & $B$ line \\
\hline B Wheatland & USA-Texas & & TX 399 B line \\
\hline RTX 430 & USA-Texas & $(\mathrm{TX} 2536 \times \mathrm{SC} 170)$ & $\mathrm{R}$ line \\
\hline RTX 432 & USA-Texas & & $\mathbf{R}$ line \\
\hline IS 11296 & Ethiopia & Caudatum, bicolor & PI 329544 \\
\hline RTX 430 TCR-20 & USA-Georgia & & Tissue culture $\mathrm{R}$ line \\
\hline RTX 430 TCR-30 & USA-Georgia & & Tissue culture $R$ line \\
\hline RTX 430 TCR-50 & USA-Georgia & & Tissue culture $\mathrm{R}$ line \\
\hline IS 2782 & East Africa & Durra-Kaura & \\
\hline IS 7180 & Nyssaland $\dagger$ & Conspicuum & \\
\hline IS 7809 & Nigeria & Caudatum-Kaura & SC $402 \mathrm{R}$ line \\
\hline IS 7318 & Nigeria & Caudatum & \\
\hline IS 9187 & Somaliland $\dagger$ & Durra & \\
\hline IS 7440 & Nigeria & Caudatum & SC $346 \mathrm{R}$ line \\
\hline IS 9785 & Sudan & Caudatum & \\
\hline IS 9919 & Sudan & Caudatum & \\
\hline IS 7243 & Nigeria & Caudatum & \\
\hline
\end{tabular}

†Nyssaland is now Malawi and Somaliland is now Somalia, Djibouti, and a part of eastern Ethiopia. 


\section{RESULTS AND DISCUSSION}

Visual symptoms for Al toxicity on upper leaves of plants are normally not specific, but interveinal chlorosis and pale green color commonly appear (Grundon et al., 1987). Aluminum-induced symptoms of phosphorus ( $\mathrm{P}), \mathrm{Ca}, \mathrm{Mg}$, and $\mathrm{Fe}$ deficiencies may be common on leaves of some genotypes. Aluminum toxicity symptoms on roots are manifest by reduced lengths or lack of extension, less lateral branching, enlarged diameters, and usually dark in color. Lateral roots especially become short and stubby, usually bunched together (coralloid), near tips of main roots. Numbers of nodal roots initiated may also increase, but extension is usually limited.

Visual symptoms of the various genotypes became more severe as Al increased (Table 2), and genotypes had varied degrees of symptoms on both leaves and roots. Rating genotypes for Al toxicity tolerance using visual symptoms appeared feasible at the $200 \mu \mathrm{M}$ Al level, but was difficult at the higher Al levels. Plants grown with 400 and $600 \mu \mathrm{M} \mathrm{Al}$ had fairly severe Al toxicity symptoms, and plants grown at $800 \mu \mathrm{M}$ Al had severe symptoms.

Shoot and root DM decreased dramatically as Al increased, regardless of genotypic group (Figure 1, upper). No significant differences for shoot DM were noted among genotypic groups, but differences for root DM were noted between $\mathrm{Al}$-tolerant and $\mathrm{Al}$-sensitive groups. Although genotypic differences for root DM were noted among genotypes, root DM differences were not as wide for evaluating plants for Al toxicity tolerance as NMARL and TRL, especially NMARL (Figure 1, lower). For example, neither SC 283, an Al tolerant genotype (Duncan, 1991), nor ICA-Nataima, a fairly Al-sensitive genotype (Flores et al., 1988; Galvez and Clark, 1991), had significant differences in shoot and root DM when grown with $\geq 400 \mu \mathrm{M} \mathrm{Al}$.

Shoot to root DM ratios of plants grown with increased levels of $\mathrm{Al}$ were consistently higher for the Al-sensitive genotypes (Table 2). However, the intermediate Al-tolerant and Al-tolerant genotypes did not increase shoot to root DM ratios above those of controls until plants were grown with $\geq 600 \mu \mathrm{M} \mathrm{Al}$. Shoot to root DM ratios for SC 283 grown with all levels of $\mathrm{Al}$ remained near or below that of the controls. Higher shoot to root DM ratios for plants grown with $\mathrm{Al}$ compared to no $\mathrm{Al}$ indicated that $\mathrm{Al}$ toxicity affected roots more than shoots. Similar responses have been reported by others (Baligar et al., 1989; Foy, 1984).

Large differences in NMARL were noted between Al-tolerant and Al-sensitive genotypic groups when plants were grown with $400 \mu \mathrm{M} \mathrm{Al}$ (Figure 1, lower left). Wide differences among genotypes were noted for TRL when plants were grown at 200 and $400 \mu \mathrm{M} \mathrm{Al}$ (Figure 1, lower right), but these differences were relatively narrow as $\mathrm{Al}$ increased above $400 \mu \mathrm{M}$. Specific $\mathrm{RL}(\mathrm{TRL} \div$ root $\mathrm{DM}$ ) was higher for SC 283 and the Al-tolerant genotypes compared to the Al-sensitive genotypes for plants grown with up to $400 \mu \mathrm{M} \mathrm{Al}$, and erratic for plants grown with $>600$ $\mu \mathrm{M} \mathrm{Al}$ (Table 2). Widest differences among genotypes for growth traits were 
TABLE 2. Ratings of visual Al toxicity symptoms, shoot to root dry matter (DM) ratios, and specific root lengths (RL) of sorghum genotypes grown with varied levels of $\mathrm{Al}$.

\begin{tabular}{|c|c|c|c|c|c|c|}
\hline \multirow[b]{2}{*}{ Trait } & \multirow[b]{2}{*}{ Genotypic group } & \multicolumn{5}{|c|}{ Level of $\mathrm{Al}(\mu \mathrm{M})$} \\
\hline & & $0^{*}$ & 200 & 400 & 600 & 800 \\
\hline Visual & SC 283 & 1.0 & 1.8 & 3.0 & 3.5 & 4.3 \\
\hline Al toxicity & Al-tolerant & 1.0 & 2.0 & 3.2 & 3.8 & 4.6 \\
\hline \multirow[t]{4}{*}{ rating ${ }^{b}$} & Intermediate Al-tolerant & 1.0 & 2.6 & 3.4 & 3.8 & 4.5 \\
\hline & Al-sensitive & 1.0 & 2.7 & 3.4 & 4.0 & 4.4 \\
\hline & $\operatorname{LSD}(0.05)$ & \multicolumn{5}{|c|}{0.4} \\
\hline & & \multicolumn{5}{|c|}{ percent of control } \\
\hline Shoot to & SC 283 & $100(1.40)$ & 89 & 95 & 95 & 95 \\
\hline root DM & Al-tolerant & $100(1.54)$ & 88 & 96 & 111 & 159 \\
\hline \multirow[t]{4}{*}{ ratio } & Intermediate Al-tolerant & $100(1.59)$ & 96 & 103 & 118 & 131 \\
\hline & Al-sensitive & $100(1.53)$ & 106 & 123 & 150 & 179 \\
\hline & LSD $(0.05)$ & & & 11 & & \\
\hline & & \multicolumn{5}{|c|}{ percent of control } \\
\hline \multirow[t]{5}{*}{ Specific $\mathrm{RL}^{\mathrm{c}}$} & SC 283 & $100(132)$ & 111 & 88 & 59 & 49 \\
\hline & Al-tolerant & $100(130)$ & 120 & 106 & 61 & 60 \\
\hline & Intermediate Al-tolerant & $100(131)$ & 88 & 58 & 58 & 58 \\
\hline & Al-sensitive & $100(128)$ & 77 & 71 & 84 & 71 \\
\hline & LSD $(0.05)$ & & & 6 & & \\
\hline
\end{tabular}

${ }^{2}$ Numbers in parentheses are actual shoot to root DM ratio and specific RL values for controls.

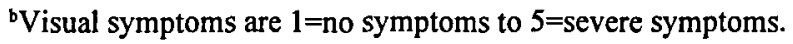

'Specific RL=total $R L \div \operatorname{root} D M\left(\mathrm{~m} \mathrm{~g}^{-1}\right)$. 

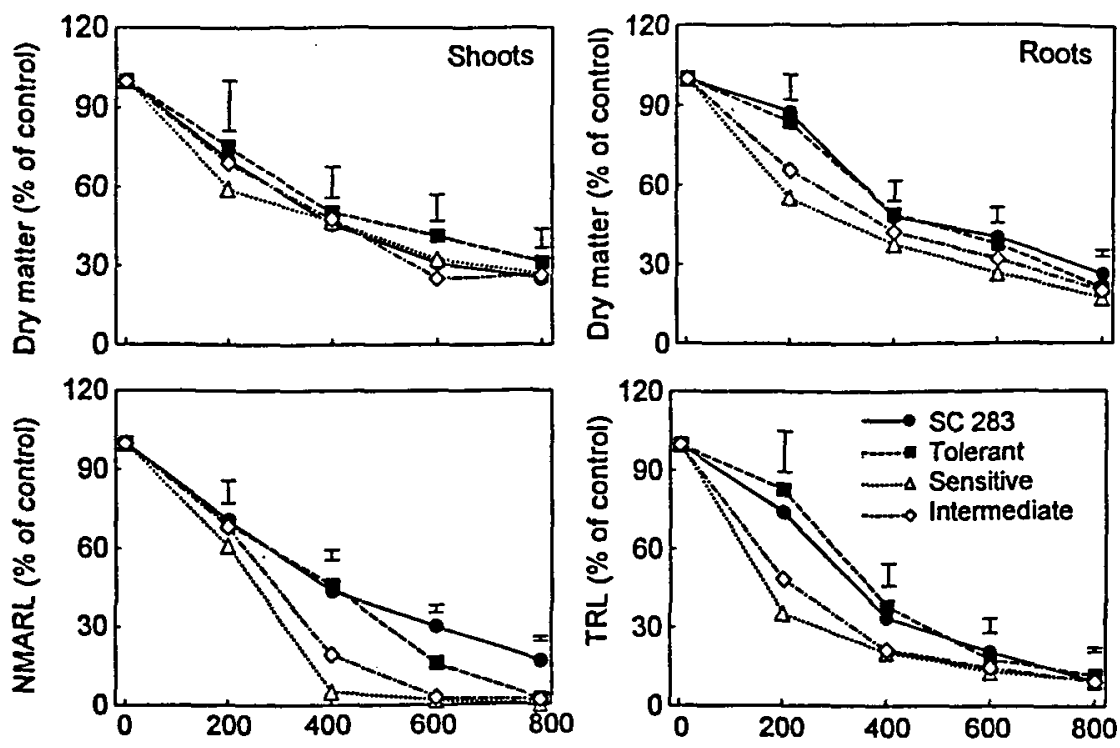

Al level $(\mu M)$

FIGURE 1. Shoot and root dry matter (upper) and net main axis root length (NMARL) and total root length (TRL) (lower) of sorghum genotypes grown with varied levels of $\mathrm{Al}$ $[I=\operatorname{LSD}(\mathrm{P}=0.05)]$.

noted for NMARL, which was used to categorize the genotypes into the groups of this study. In other studies, longest adventitious root lengths and NMARL were the best traits to evaluate sorghum for Al toxicity tolerance compared to shoot and root DM, visual symptoms, number of adventitious roots initiated, and mean seminal RL (Furlani and Clark, 1987). However, visual symptoms, fresh root weights, and total and lateral root lengths were effective in separating tolerant and sensitive maize (Zea mays L.) in the greenhouse for evaluation in the field (Urrea-Gómez et al., 1996). The Al-tolerant genotypes and SC 283 had higher specific RL than Al-sensitive genotypes when grown with $\mathrm{Al}$, which indicated that roots of Al-tolerant genotypes remained finer, smaller in diameter, and had more branching than roots of Al-sensitive genotypes.

In summary, root DM had fairly wide differences among genotypes when plants were grown with various levels of Al, but shoot DM did not. Total RL and NMARL had large differences among genotypes, and these two traits could be used more effectively than root DM to evaluate differences among sorghum genotypes for tolerance to $\mathrm{Al}$ toxicity. 


\section{ACKNOWLEDGMENTS}

Preparation of the figure by Ms. S. S. Boyer is greatly appreciated.

\section{REFERENCES}

Baligar, V.C., H.L. Dos Santos, G.V.E. Pitta, E.C. Filho, C.A. Vasconcellos, and A. F. de C. Bahia Filho. 1989. Aluminum effects on growth, grain yield and nutrient use efficiency ratios in sorghum genotypes. Plant Soil 116:257-264.

Barrow, N.J. (ed.). 1993. Plant Nutrition-From Genetic Engineering to Field Practice. Kluwer Academic Publishers, Dordrecht, The Netherlands.

Clark, R.B. 1982. Nutrient solution growth of sorghum and corn in mineral nutrition studies. J. Plant Nutr. 5:1039-1057.

Date, R.A., N.J. Grundon, G.E. Rayment, and M.E. Probert (eds.). 1995. Plant-Soil Interactions at Low pH: Principles and Management. Kluwer Academic Publishers, Dordrecht, The Netherlands.

Duncan, R.R. 1991. Acid soil tolerance breeding in sorghum. Adv. Agron. (India) 1:7179.

Flores, C.I., R.B. Clark, and L.M. Gourley. 1988. Growth and yield traits of sorghum grain on acid soil at varied aluminum saturations. Plant Soil 106:49-57.

Foy, C.D. 1984. Physiological effects of hydrogen, aluminum, and manganese toxicities in acid soil. pp. 57-97. In: F. Adams (ed.), Soil Acidity and Liming. 2nd ed. American Society of Agronomy, Madison, WI.

Foy, C.D. 1992. Soil chemical factors limiting plant root growth. Adv. Soil Sci. 19: 97149.

Foy, C.D. 1993. Role of the soil scientist in genetic improvement of plants for problem soils. pp. 185-205. In: J.W. Maranville, V.C. Baligar, R.R. Duncan, and J.M. Yohe (eds.), Proceedings on Adaptation of Plants to Soil Stresses. INTSORMIL (Publication No. 94-2), University of Nebraska, Lincoln, NE.

Furlani, P.R. and R.B. Clark. 1987. Plant traits to evaluate sorghum genotypic responses to aluminum. pp. 247-254. In: W.H. Gabelman and B.C. Loughman (eds.), Genetic Aspects of Plant Mineral Nutrition. Martenus Nijhoff Publishers, Dordrecht, The Netherlands.

Galvez, L. and R.B. Clark. 1991. Nitrate and ammonium uptake and solution pH changes for Al-tolerant and Al-sensitive sorghum [Sorghum bicolor (L.) Moench.] grown with and without aluminum. pp. 805-814. In: R.J. Wright, V.C. Baligar, and R.P. Murrmann (eds.), Plant-Soil Interactions at Low pH. Kluwer Academic Publishers, Dordrecht, The Netherlands. 
Grundon, N.J., D.G. Edwards, P.N. Takkar, C.J. Asher, and R.B. Clark. 1987. Nutritional disorders of grain sorghum. Australian Centre for International Agricultural Research, Canberra, Australia..

Howeler, R.H. and L.F. Cadavid. 1976. Screening rice cultivars for tolerance to Altoxicity in nutrient solutions as compared with a field screening method. Agron. J. 68:551-555.

Maranville, J.W., V.C. Baligar, R.R. Duncan, and J.M. Yohe (eds.). 1993. Proceedings on Adaptation of Plants to Soil Stresses. INTSORMIL (Publication No. 94-2), University of Nebraska, Lincoln, NE.

Newman, E.I. 1966. A method of estimating the total length of root in a sample. J. Appl. Ecol. 3:139-145.

SAS. 1985. SAS User's Guide: Statistics. 5th ed. Statistical Analysis System Institute, Cary, NC.

Tennant, D. 1975. A test of a modified line intersect method of estimating root length. J. Ecol. 73:995-1001.

Urrea-Gómez, R., H. Ceballos, S. Pandey, A.F.C. Bahía Filho, and L.A. León. 1996. A greenhouse screening technique for acid soil tolerance in maize. Agron. J. 88: 806812.

Wright, R.J., V.C. Baligar, and R.P. Murrmann (eds.). 1991. Plant-Soil Interactions at Low pH. Kluwer Academic Publishers, Dordrecht, The Netherlands. 